\title{
Diagnoza: niemiłość? Działania pozorne a system wsparcia dzieci i młodzieży po próbach samobójczych
}

\author{
Paulina Adamczyk \\ Uniwersytet Łódzki
}

DOI: http://dx.doi.org/10.18778/1733-8069.17.1.08

\section{Słowa kluczowe: samobójstwo, próba samobójcza, opieka psychiatryczna, działania pozorne, socjologia dzieci i młodzieży, rodzina}

\begin{abstract}
Abstrakt: Mimo coraz liczniejszych doniesień medialnych na temat rosnącego kryzysu systemu opieki psychologicznej i psychiatrycznej oraz powiązanego z nim wzrostu liczby zachowań samobójczych wśród dzieci i młodzieży, temat ten wciąż nie staje się istotnym elementem debaty politycznej. W oparciu o analizę literatury przedmiotu, danych statystycznych i przekazów medialnych dotyczących problematyki psychiatrii dzieci i młodzieży w Polsce w artykule podjęto próbę opisania w kategoriach socjologicznych wybranych kontekstów sytuacji kryzysowej. Uwagę szczególnie skoncentrowano na problematyce często stabuizowanych w polskim kontekście relacji rodzinnych oraz ich znaczenia jako czynnika o niejednoznacznym wpływie na dzieci i młodzież, także w procesie terapeutycznym po próbach samobójczych. W artykule podejmuje się również rozważania na temat instytucjonalnego kryzysu polskiego systemu opieki zdrowotnej w zakresie psychologii i psychiatrii.
\end{abstract}

Paulina Adamczyk, doktorantka w Katedrze Socjologii Polityki i Moralności na Wydziale Ekonomiczno-Socjologicznym Uniwersytetu Łódzkiego. Zainteresowana jest problematyką badawczą obejmującą zdrowie psychiczne, ze szczególną koncentracją na dzieciach i młodzieży oraz na tematach związanych z samobójstwem i autodestrukcją.
Adres kontaktowy:
Katedra Socjologii Polityki i Moralności
Wydział Ekonomiczno-Socjologiczny
Uniwersytet Łódzki
ul. Rewolucji 1905 r. nr 41/43, 90-214 Łódź
e-mail: paulina.maria.adamczyk@wp.pl 
W największych polskich mediach ze wszystkich stron politycznego spektrum pojawiają się regularnie coraz liczniejsze doniesienia i materiały dziennikarskie o kryzysie polskiego systemu psychologicznej i psychiatrycznej opieki nad dziećmi i młodzieżą (zob. Suchodolska 2018; Palińska 2019; Nowakowska 2020; Pinkosz 2020; Schwertner 2020). Mimo rosnącego zainteresowania mediów informujących opinię publiczną o strukturalnych problemach oraz ich konsekwencjach problematyka ta nie stała się jak do tej pory istotnym wątkiem dyskursu o zobowiązaniach państwa wobec obywateli i ich jakości życia, ani tematem politycznych debat. Pomimo przywoływania $\mathrm{w}$ hasłach politycznych dobra rodziny przedmiotem zainteresowania nie są także nieprawidłowe więzi rodziców z dzieckiem czy brak miłości rodzicielskiej, wpływające na funkcjonowanie młodej osoby jako odrębnej jednostki, tworzone przez nią relacje, a ostatecznie niekiedy na jej decyzję o zakończeniu swojego życia. W obliczu takiej sytuacji jednostka z jednego chwiejnego gruntu, jakim jest rodzina, trafia na grunt równie niestabilny - na instytucjonalne rozwiązania systemowe dla osób w kryzysie psychicznym.

Temat samobójstwa należy do fundamentalnych zagadnień co najmniej od czasu klasycznej pracy Émila Durkheima (2011), podejmowanych regularnie w teoretycznych rozważaniach oraz empirycznych pracach badaczy ze wszystkich dyscyplin nauk społecznych oraz humanistycznych. Biorąc pod uwagę skalę zjawiska, nie stanowi jednak dzisiaj istotnego elementu debaty akademickiej w Polsce - jakby istniało przekonanie, że problematyka zachowań samobójczych została już wyczerpana, a dalsza eksploracja jest niepotrzebna. Wśród nielicznych prac powstałych na ten temat należy przywołać studia socjologiczne (w tym: Rosa 2012; Wróblewski 2012; 2016; Rosa, Czabański
2014), psychologiczne i psychiatryczne (w tym: Gmitrowicz, Krawczyk 2014; Gmitrowicz i in. 2015; Makara-Studzińska 2017), a także i antropologiczne (w tym: Witeska-Młynarczyk 2018).

Artykuł ten stawia sobie za cel poszerzenie istniejącej już dyskusji, stanowi także socjologiczny szkic będący wynikiem analizy literatury przedmiotu, danych statystycznych i przekazów medialnych dotyczących problematyki psychiatrii dzieci i młodzieży w Polsce. Eksploracja tego obszaru stanowi wstęp do szczegółowego ukierunkowania pracy badawczej autorki w przyszłości. W pierwszej części omówione zostały podstawowe dane dotyczące kwestii zachowań samobójczych w Polsce, następnie skoncentrowano się na dwóch wątkach zasługujących zdaniem autorki na szczególną refleksję. Pierwszy z nich dotyczy znaczenia rodziny jako kluczowego i oddziałującego wielowymiarowo czynnika mającego niejednoznaczny wpływ zarówno na decyzje samobójcze i budowanie atmosfery presuicydalnej (ang. pre-suicidal), jak i na proces terapeutyczny po próbach samobójczych. Druga podjęta kwestia dotyczy procesu zdrowienia, w szczególności instytucjonalnego zaplanowania i zorganizowania systemu opieki i wsparcia w polskim systemie polityki zdrowia publicznego. Oba podjęte w artykule wątki omówione zostały $\mathrm{w}$ socjologicznych kategoriach fasadowości działań instytucjonalnych (Berger, Luckmann 1983; Berger 1997) oraz działań pozornych (Lutyński 1990; 1996). W tym zakresie artykuł nie aspiruje do zbudowania spójnego teoretycznego podejścia do opisywanych problemów, ale raczej sięga do różnych inspiracji, budując eklektyczny teoretycznie obraz opisywanych zjawisk, wskazując na relewantność różnych pojęć i koncepcji.

W artykule podjęto próbę odpowiedzi na następujące pytania szczegółowe: czy wsparcie ze strony 
rodziców może być niewystarczające? W jaki sposób rodzina może być jednym z czynników ryzyka podjęcia zachowania samobójczego? Czy przyjęte metody leczenia dzieci i młodzieży po próbie samobójczej sięgają głębi problemu? Czy stosowana jako uniwersalne rozwiązanie hospitalizacja rzeczywiście jest odpowiedzią na negatywne wzory zachowania wśród znaczących innych tych młodych osób? Czy poprzez realizowane w Polsce leczenie znika bodziec popychający do decyzji o odebraniu sobie życia? A może przyjmowane przez nas jako społeczeństwo argumenty są jedynie zasłoną, która zakrywa niewygodny problem zamiast zapewnić ochronę cierpiącym jednostkom?

\section{Samobójstwa i próby samobójcze w Polsce - zarys zjawiska}

Samobójstwo postrzegane jest jako rezygnacja jednostki z życia na skutek cierpienia, z którym nie może ona sobie poradzić (Zwoliński 2013). W celu opracowania skutecznej prewencji wskazuje się na możliwe czynniki ryzyka, nie jest bowiem możliwe udzielenie prostej odpowiedzi na pytanie „dlaczego" czy "jacy” ludzie decydują się na ten krok. Upraszczający osąd na temat przyczyn samobójstwa przyjmuje często formę dychotomicznego kontrastu odwaga versus tchórzostwo, co znajduje swoje odzwierciedlenie chociażby na forach internetowych (Tuszyńska-Bogucka 2017). Przyjęcie którejkolwiek z tych perspektyw nie ma jednak nic wspólnego z jednostkowymi dramatami osób popełniających samobójstwo, a staje się krzywdzące dla rodziny ofiary czy człowieka po próbie samobójczej, wracającego do społeczeństwa.

Zgodnie z danymi pochodzącymi z Komendy Głównej Policji w 2019 roku samobójstwo popełniło 5255 osób, z czego 98 nie ukończyło osiemnastego roku życia. Natomiast liczba odnotowanych przez policję zachowań samobójczych (tj. tych zakończonych zgonem i tych kwalifikowanych jako próby samobójcze łącznie) w tej grupie wiekowej wynosiła aż 951. Duży wzrost w liczbie zamachów samobójczych w statystykach policyjnych nastąpił w 2017 roku (730 wśród osób niepełnoletnich, rok wcześniej 475), co prawdopodobnie wiąże się ze zmianą trybu zgłaszania zachowania samobójczego, który od wspomnianego roku odnotowywany jest poprzez formularz KSIP $10^{1}$. Szczegółowy rozkład danych został zaprezentowany w tabeli 1, gdzie uwzględniono łączną liczbę zachowań samobójczych, w nawiasie podając natomiast liczbę tych, które zakończyły się zgonem. Jednocześnie warto podkreślić, iż nie należy bezwzględnie opierać się na statystykach dotyczących samobójstw w Polsce, ponieważ są one znacznie niedoszacowane. Wnikliwie temat ten omówił w jednym ze swoich artykułów Krzysztof Rosa (2012).

\section{Tabela 1. Zachowania samobójcze dzieci} i młodzieży w Polsce w latach 2013-2019

\begin{tabular}{|c|c|c|c|c|c|c|c|}
\hline & 2013 & 2014 & 2015 & 2016 & 2017 & 2018 & 2019 \\
\hline Wiek 0-6 & 0 & 0 & 0 & 0 & 0 & 0 & 0 \\
\hline Wiek 7-12 & $\begin{array}{l}9 \\
(4)\end{array}$ & $\begin{array}{l}14 \\
(3)\end{array}$ & $\begin{array}{l}12 \\
(5)\end{array}$ & $\begin{array}{l}9 \\
(2)\end{array}$ & $\begin{array}{l}28 \\
(1)\end{array}$ & $\begin{array}{l}26 \\
(5)\end{array}$ & $\begin{array}{l}46 \\
(4)\end{array}$ \\
\hline Wiek 13-18 & $\begin{array}{c}348 \\
(144)\end{array}$ & $\begin{array}{c}428 \\
(124)\end{array}$ & $\begin{array}{c}469 \\
(114)\end{array}$ & $\begin{array}{r}466 \\
(101)\end{array}$ & $\begin{array}{c}702 \\
(115)\end{array}$ & $\begin{array}{l}746 \\
(92)\end{array}$ & $\begin{array}{l}905 \\
(94)\end{array}$ \\
\hline Razem & $\begin{array}{c}357 \\
(148)\end{array}$ & $\begin{array}{r}442 \\
(127)\end{array}$ & $\begin{array}{c}481 \\
(119)\end{array}$ & $\begin{array}{r}475 \\
(103)\end{array}$ & $\begin{array}{c}730 \\
(116)\end{array}$ & $\begin{array}{l}772 \\
(97)\end{array}$ & $\begin{array}{l}951 \\
(98)\end{array}$ \\
\hline
\end{tabular}

Źródło: opracowanie własne na podstawie danych Komendy Głównej Policji.

\footnotetext{
${ }^{1}$ KSIP 10 - od 2017 roku „zgłoszenie zamachu/zachowania samobójczego”, wcześniej nosił nazwę „rejestracja zgłoszenia zamachu samobójczego" i zawierał mniejszy zakres danych o zdarzeniu.
} 
Samobójstwa oraz próby samobójcze są zjawiskiem niedającym uchwycić się $\mathrm{w}$ ramach istniejących wskaźników i statystyk - dane w nich ujęte są jedynie wycinkiem rzeczywistości społecznej. Podobnie wygląda sytuacja dotycząca przyczyn zamachu na swoje życie. Policyjne dane identyfikują prawdopodobny powód $\mathrm{w}$ mniej niż połowie przypadków. Wskazują przy tym na jeden konkretny aspekt, taki jak problemy finansowe, długotrwała choroba czy mobbing. Tymczasem w suicydologii oraz psychologii podkreśla się współwystępowanie wielu czynników suicydogennych następujących po sobie lub nakładających się na siebie i tworzących tak zwaną atmosferę samobójczą (lub inaczej: presuicydalną). Wówczas wystarczy jeszcze jedno wydarzenie, jedna osoba czy jedna chwila, by wpłynąć na podjęcie tak drastycznej decyzji.

Według policyjnych statystyk w 2019 roku miało miejsce 5255 samobójstw zakończonych zgonem, jednocześnie przyczynę² ustalono zaledwie w 2159 przypadkach, co nie stanowi nawet połowy. Mimo powyższych zastrzeżeń faktem jest, iż drugim, najczęstszym powodem podjęcia próby samobójczej identyfikowanym przez policję, po chorobach i zaburzeniach psychicznych (963), były właśnie nieporozumienia i przemoc $\mathrm{w}$ rodzinie (259) (Komenda Główna Policji 2020).

\section{Rodzina jako niejednoznaczny czynnik suicydogenny}

Współczesne przeobrażenia relacji, wśród których wymienia się przede wszystkim przyjmowanie innej formy rodziny niż nuklearna, odejście od auto-

\footnotetext{
${ }^{2}$ Jak próbowano wykazać wcześniej, jest to jednak raczej ostateczny czynnik, który utwierdził jednostkę w tej decyzji, przy czym należy pamiętać, że dane policyjne w tym temacie obarczone są pewnymi błędami poznawczymi.
}

rytarnego stylu wychowania, ale też rozluźnienie więzi społecznych z innymi ludźmi, tworzenie powierzchownych znajomości oraz współwystępujące poczucie osamotnienia, niepokoju i lęku (Szarota 2018; Frączek 2019), przyczyniają się do wzrostu popularności trendu przeciwnego: tak zwanego tradycyjnego modelu wychowania jako odpowiedzi na wspomniane wyżej zmiany. Często do tych tradycyjnych wartości zalicza się przekonanie, że dziecko powinno być posłuszne rodzicom i reagować zgodnie $\mathrm{z}$ ich oczekiwaniami - w tym celu stosowano $\mathrm{w}$ przeszłości przemoc fizyczną, której występowanie racjonalizowano potrzebą „silnej ręki" w wychowaniu. Dorosłe już ofiary powtarzały następnie znany sobie schemat wobec swoich własnych dzieci, tworzac tym samym błędne koło przemocy. Analizę tradycyjnego postrzegania rodziny (ze szczególnym uwzględnieniem niezaprzeczalnej i niekwestionowalnej władzy rodzicielskiej) oraz rozwiązań systemowych „ingerujących” w tę rodzinę przeprowadzili Magdalena Rek-Woźniak oraz Wojciech Woźniak w pracach dotyczących debaty wokół wprowadzenia zakazu stosowania wobec dzieci przemocy fizycznej (Rek-Woźniak, Woźniak 2014; 2013). W ramach niniejszego tematu warto chociażby odwołać się do omawianej przez nich tezy, iż idealizowanie rodziny tradycyjnej, zamkniętej na wpływy z zewnątrz, kłóci się z trendem upodmiotowienia dzieci i młodzieży i traktowania ich jako jednostek obdarzonych swoją wola, pragnieniami czy potrzebami. W niektórych środowiskach specjaliści pracujący w szpitalnym oddziale psychiatrycznym niczym nie różnią się od omawianych we wspomnianym artykule pracowników socjalnych, którzy postrzegani są nie jako eksperci czy pomoc z poziomu makro, lecz właśnie jako „ingerencja" w poziom mikro, to jest w strukturę rodzinną i wychowanie. Tradycja w tym rozumieniu tożsama jest $\mathrm{z}$ brakiem wzrostu świadomości wy- 
chowawczej i z akceptacją błędów wychowawczych popełnianych przez rodziców oraz ich przekazywania z pokolenia na pokolenie. Tym samym działania na rzecz ochrony praw dzieci (w tym wzmocnienie ich podmiotowości) traktowane są jako atak na rodzinę i prawa rodziców do wychowywania ich zgodnie $\mathrm{z}$ własnymi wartościami. W tym znaczeniu słusznym jest użycie określenia „władza rodzicielska”, gdyż rzeczywiście jest to władza silniejszego nad słabszym (Kamińska 2010).

Dziecko początkowo wychowuje się w świecie swoich rodziców/opiekunów, ich konstrukcje rzeczywistości są więc zbieżne, podobnie jak postrzeganie choroby czy (nie)zdrowych czynności (Maciejewska-Mroczek 2018). Dziecko czy nastolatek konfrontuje jednak swoje przekonania z rzeczywistością i zdarza się, że jego konstrukty przestają być zgodne z tymi utworzonymi przez rodziców. Przestaje wówczas przyjmować przekazywaną mu interpretację rzeczywistości społecznej, a zaczyna zadawać pytania - zarówno samemu sobie, jak i rodzicom. Następnie na podstawie własnej eksploracji tworzy swój osobisty system wartości (Tillmann 2006). Rodzice czy opiekunowie postrzegają często ten okres jako bunt, który należy stłumić lub „utemperować”, ignorując podmiotowość młodej jednostki.

W sytuacji kryzysu psychicznego dziecko lub nastolatek może więc doświadczyć niezrozumienia ze strony najbliższego otoczenia. Powody takiej sytuacji są rozmaite - od problemów w komunikacji w rodzinie po złe doświadczenia rodziców ze specjalistami od zdrowia psychicznego. Wskazać można również tutaj niedostrzeganie przez rodziców otrzymywanych sygnałów czy głośne werbalizowanie swojego braku poparcia dla leczenia psyche i utożsamianie psychiatrów oraz psychologów z szamanami lub naciągaczami. Jednocześnie poczucie wstydu czy posłuszeństwo wobec woli rodziców okazują się niekiedy silniejsze niż potrzeba zwrócenia się po pomoc na zewnątrz.

Wśród osób młodych czynniki suicydogenne dotyczące rodziny to przede wszystkim obecne $\mathrm{w}$ niej: przemoc (fizyczna, seksualna, werbalna), uzależnienie od alkoholu (lub innych środków psychoaktywnych), zaburzenia psychiczne występujące u opiekunów, rozwód rodziców lub śmierć któregoś z nich we wczesnym dzieciństwie jednostki (Stanisławska-Kubiak, Matecka, Mojs 2010). Większość tych czynników może kojarzyć się z szerokim pojęciem dysfunkcjonalności. W najprostszym rozumieniu oznacza ona niewypełnianie przypisanych funkcji - w socjologii jest to zobowiązanie wobec grupy (rodziny) oraz całego społeczeństwa, natomiast w psychologii wobec jednostki, jej stanu psychicznego oraz prawidłowego rozwoju (Maciejewska, Bury 2008).

Według raportu Fundacji Dajemy Dzieciom Siłę (2018) przemocy fizycznej, rozumianej jako uderzenie, kopnięcie lub klapsy ${ }^{3}$ ze strony bliskich dorosłych, doświadczyło 41\% badanych w wieku 11-17 lat, a najczęściej sprawcą był ojciec (28\%) lub matka (21\%). Jednak co ważne, aż 43\% młodych osób nie wskazało sprawcy przemocy. Podobnie z przemocą psychiczną, której doznało $20 \%$ badanych - $26 \%$ spośród nich nie chciało odpowiedzieć, kto ją stosował, 33\% doświadczyło jej ze strony ojca oraz 33\% ze strony matki. I chociaż te wartości procentowe nie są małe, to należy pamiętać, że w rzeczywistości mogą być one jeszcze wyższe - ze względów metodologicznych oraz etycznych, by wziąć udział

\footnotetext{
${ }^{3}$ Przy czym nie analizowano tutaj ,jednorazowych" klapsów - do analizy włączono przypadki, w których dziecko otrzymywało klapsa co najmniej kilka razy w trakcie roku. Badanie miało charakter reprezentatywny i obejmowało próbę 1155 uczniów w wieku 11-17 lat.
} 
w badaniu, wymagana była bowiem zgoda rodzica. Zapewne więc część matek i ojców dopuszczających się przemocy lub zaniedbań wobec swojego dziecka nie wyraziła zgody na jego udział $\mathrm{w}$ badaniu dotyczącym tak drażliwego tematu. W 2019 roku Pogotowie „Niebieska Linia” odebrało 534 połączeń telefonicznych od dzieci lub młodzieży, w tym 38\% (180) zgłaszało przemoc psychiczną, a 28\% (147) przemoc fizyczną. Podjęto łącznie 369 interwencji w sprawach dotyczących przemocy w rodzinie, a 59,2\% tych spraw dotyczyło dziecka jako ofiary tejże przemocy (Ogólnopolskie Pogotowie dla Ofiar Przemocy w Rodzinie „Niebieska Linia” 2020).

Alkoholizm, narkomanię, przemoc można byłoby więc określić jako „twarde” wskaźniki dysfunkcjonalności rodziny, co sugerowałoby potrzebę wyróżnienia również „miękkich” wskaźników, zdecydowanie trudniejszych do uchwycenia, a więc i do zmiany. Podejmując bowiem próbę wyjaśnienia skutków poprzez znajdowanie przyczyny, czyli zastanawiając się nad tym, co wpływa negatywnie na prawidłowy rozwój jednostki w komórce rodzinnej, a następnie na jej funkcjonowanie w społeczeństwie, dość szybko można dojść do wniosku, iż przyczyn jest znacznie więcej niż te wymienione wyżej. Wśród nich znalazłyby się na przykład parentyfikacja (tj. odwrócenie ról $\mathrm{w}$ rodzinie, dziecko przyjmuje rolę rodzica, opiekuna), nadopiekuńczość lub zaniedbanie, obniżanie poczucia własnej wartości u dziecka, zawstydzanie go czy brak stabilności emocjonalnej rodziców (Maciejewska, Bury 2008). Idąc dalej, wskazać można kolejne negatywne wzorce zachowań: nakładanie na dzieci presji osiągnięć; tworzenie tak zwanego "projektu dziecko” nieuwzględniającego jego potrzeb i emocji; szeroko rozumiany brak akceptacji dla jego wyborów, a także dla jego seksualności, orientacji czy (nie)religijności. Negatywnie wpływają także takie czynniki jak nieefektywna komunikacja w rodzinie czy niespójne podejście rodziców do wychowania (Lewicka-Pańczak 2014). Według niektórych badaczy zdecydowana większość rodzin jest w pewnym stopniu dysfunkcjonalna, jednak zagrożenie dla jednostek pojawia się w sytuacji, gdy bezpieczny próg zostanie przekroczony i dysfunkcjonalność przekształca się w destrukcyjność (Maciejewska, Bury 2008).

Jednocześnie bezwarunkowa miłość rodzica do dziecka przyjmowana jest za oczywistość. Różnorodne akty odrzucenia czy zaniedbania dziecka utożsamiane są powszechnie $\mathrm{z}$,ppatologiczną sytuacją" czy „byciem wyrodnym rodzicem”, co znajduje swoje odzwierciedlenie w dyskursie medialnym, zwłaszcza w przyciągających wzrok nagłówkach wiadomości. Głównie dotyczy to matek, co wynika z uwarunkowań kulturowych tejże roli społecznej (Badora 2011). Gdy w polskiej kulturze dorosłe kobiety nie wyrażają chęci posiadania dzieci lub przyznają, iż za nimi nie przepadają, słyszą zazwyczaj od innych kobiet, że "jeszcze im się zmieni” czy „zobaczą, gdy będą mieć swoje”. Jakby wraz z chwilą zapłodnienia w przyszłych rodzicach kiełkować miało ciepło, troska i odpowiedzialność, nawet jeżeli wcześniej była to im zupełnie obca postawa. I chociaż należy przyjąć, iż urodzenie dziecka jest na tyle przełomowym wydarzeniem w życiu jednostki, że rzeczywiście $w$ jej zachowaniu i postrzeganiu świata zachodzi wiele zmian, to $\mathrm{w}$ przypadku miłości rodzicielskiej nie jest to wcale zawsze powtarzający się ciąg przyczynowo-skutkowy (Badora 2011).

\section{Za fasadą - pozorność wsparcia $\mathrm{w}$ rodzinie}

Pomimo niewątpliwie posiadanej przez dziecko podmiotowości, słusznie wskazuje się na pewien fatalizm socjalizacji pierwotnej - „osobowość jest 
wynikiem odbicia, mianowicie odbija ona postawy przyjmowane najpierw wobec niej przez znaczących innych" (Berger, Luckmann 1983: 206), których jednostka nie może wybrać, a którzy przekazująjej własną interpretację rzeczywistości jako rzeczywistość obiektywną. Może to wiązać się z narastaniem konfliktów w relacjach rodzic-dziecko, będących efektem konfrontacji systemu wartości rodziców z jego alternatywną formą. Funkcjonowanie $\mathrm{w}$ ramach odmiennego uniwersum przyczynia się natomiast do obalenia mitu jedynej słusznej perspektywy. Dla rodziców oznacza to konieczność zweryfikowania swoich wartości, co zależne jest z kolei od otwartości i gotowości na zmiany, natomiast dla dziecka jest to konflikt pomiędzy światem społecznym znaczących innych z okresu dzieciństwa a światem poznanym i przyjętym jako „swój”.

O obciążającej odpowiedzialności młodej jednostki za swoje wybory pisał już w latach 90. Klaus-Jürgen Tillmann (2006: 262): „w porównaniu z wcześniejszymi pokoleniami dzisiejsza młodzież nie tylko może w większym zakresie decydować o sobie - ona musi decydować o sobie". Tymczasem nieustanny postęp technologiczny nie ułatwia wyboru, wręcz przeciwnie - wydaje się, że im szybciej komputery przetwarzają skondensowane dane, tym szybszych i bardziej złożonych decyzji wymaga się od współczesnego człowieka. Konstruowanie swojej tożsamości nie jest już tak prostolinijne, a „każdy wydaje się pochłonięty nieustannym poszukiwaniem samego siebie, a może raczej najlepiej skrojonej autokreacji" (Szarota 2018: 3). Od lat wiadomo, że brak wsparcia $\mathrm{u}$ najbliższych osób $\mathrm{w}$ trakcie trwania tego procesu skutkować może poważnym kryzysem tożsamości (Tillmann 2006). Podobnie dzieje się ze wsparciem pozornym, którego skutki z powodu tejże właśnie iluzoryczności trudniej zrozumieć zarówno dziecku, jak i osobom z zewnątrz.
Pozorność wsparcia i akceptacji dziecka pozwala potwierdzić prawidłowe wypełnianie funkcji wychowawczych jednostkom spoza tego systemu, co przypomina pozorność opisaną przez Jana Lutyńskiego, dotyczącą różnicy między stanem zakładanym i prezentowanym a stanem rzeczywistym. Wyróżnił on następujące cechy charakteryzujące działania pozorne, przy czym każda kolejna jest właściwie uzupełnieniem poprzedniej: (1) działania te uznawane są za istotne w perspektywie realizacji społecznie ważnego celu, (2) jednak nie realizują go ani w sposób bezpośredni, ani pośredni, (3) wszyscy lub zdecydowana większość jednostek funkcjonujących w obrębie danego systemu wiedzą o tej rozbieżności, (4) wiedza ta nie jest przekazywana poza system - nie jest upubliczniona, (5) działania te podejmowane są ze względu na początkowe uznanie ich jako istotnych $\mathrm{w}$ realizacji zamierzonego celu, (6) zawierają one element fikcji (dotyczący ich przebiegu lub celu) (Lutyński 1990; 1996). Na fasadowość wsparcia w rodzinie wskazywać mogą różne czynniki, poniżej przytoczono kilka z nich.

\section{Pozorna podmiotowość nadawana dzieciom $\mathrm{w}$ relacjach $\mathrm{z}$ dorosłymi}

Jej iluzoryczny charakter dobrze oddaje tworzenie takich instytucji jak Sejm Dzieci i Młodzieży przy jednoczesnym pielęgnowaniu przekonania, że dzieci o odmiennym zdaniu niż dorośli to dzieci nieposłuszne i zbuntowane (Golus 2018). Doskonale uwidacznia się to $w$ tradycyjnym modelu rodziny, gdzie relacje rodzinne często charakteryzuje adultyzm, czyli dyskryminacja osób młodych z powodu ich wieku. Jednostki te postrzegane są jako pozbawione własnego głosu, własnych emocji, potrzeb i opinii, a ich byt określany jest jako faza przejściowa w drodze ku dorosłości, niewymagająca takiej uwagi jak faza końcowa, czyli stanie się dorosłym (Golus 2018; 
Witeska-Młynarczyk 2018). Podejście to pozwala utrzymać koncepcję władzy rodzicielskiej oraz słuszności zdania dorosłych, którzy dowolne rodzinne spory mogą zakończyć odwołaniem do tego właśnie argumentu ${ }^{4}$. Jednocześnie dyskryminacja ta jest doświadczeniem zbiorowym, przez co bywa oczywista i nieuświadomiona, co z kolei prowadzi do powtórzenia schematu $\mathrm{w}$ przypadku relacji ze swoim dzieckiem (Golus 2018). Obecnie wzmocnienie działań służących odebraniu podmiotowości dzieciom na rzecz powrotu do pełnej władzy rodzicielskiej dostrzegamy w dyskursie politycznym, a konkretnie w jego konserwatywnym nurcie, co pozwala potwierdzać aktualność tego tematu ${ }^{5}$.

\section{Miłość warunkowa}

Za zagrożenie dla dziecka uważa się brak ciepła rodzinnego. Podobny efekt przynosi jednak warunkowe okazywanie miłości, gdy dziecko obdarzane jest ogromną troską i ciepłem, lecz dopiero po spełnieniu oczekiwań matki/ojca lub opiekunów. Rodzic staje się wówczas sędzią decydującym o tym, czy jest zadowolony z postępowania swojego dziecka, a sam proces odbywa się każdego dnia od początku. Jeśli dziecko „zasłużyło” na miłość, otrzymuje ją, jeśli jednak nie - manifestowane jest w różnorod-

\footnotetext{
${ }^{4} \mathrm{Z}$ postawą tą zdecydowanie nie zgadzają się przedstawiciele i przedstawicielki interdyscyplinarnego nurtu w nauce zajmującego się złożonym zagadnieniem, jakim jest doświadczanie dzieciństwa - childhood studies, w ramach którego dzieci traktowane są jako pełnowartościowi aktorzy społeczni, wypowiadający się w swoim własnym imieniu bez zapośredniczenia $\mathrm{w}$ postaci osoby dorosłej.

${ }^{5}$ Za przykład posłużyć może działalność polityczna i publikacyjna dr hab. nauk prawnych z Katolickiego Uniwersytetu Lubelskiego oraz posła PiS, Przemysława Czarnka (2018), który w swoim artykule Konstytucyjnoprawna ochrona dziecka w książce Prawo karne w ochronie praw dziecka (Grześkowiak, Zgoliński [red. nauk.]) (!) nie tylko sugeruje, że kary cielesne bywają słusznym rozwiązaniem, lecz także, powołując się na Katolicka etyke wychowawcza, przekazuje instrukcję, w jaki sposób powinny być one wymierzane.
}

ny sposób odrzucenie. Jest więc uwikłane w zabieganie o miłość wymagającego i kontrolujące rodzica, co obniża jego samoocenę oraz przyczynia się do utraty poczucia własnej autonomii. W relacji rodzinnej sytuacja ta skutkuje niekiedy zaburzeniami odżywiania (m.in. anoreksją, zazwyczaj w relacji matka-córka). Oczywiście anoreksja jest złożonym problemem, na który składają się także pewne indywidualne predyspozycje oraz czynniki kulturowe, jednak wpływ relacji w rodzinie okazuje się tutaj bardzo ważny (Witkowska 2013). Przyjrzenie się całemu systemowi rodzinnemu jest jednym z podstawowych elementów skutecznej terapii, ponieważ „dysfunkcjonalne relacje wewnątrzrodzinne, którym często towarzyszą symptomy psychopatologii przejawiane przez rodziców, pozostają w związku z rozwojem i podtrzymywaniem zaburzeń odżywiania się" (Palus 2006: 239). Rodzina to nie tylko geny, lecz i przekazywane wzorce zachowań i tworzenia relacji, co oznacza, że cechy osobowości rodziców odgrywają istotną rolę $\mathrm{w}$ procesie kształtowania młodej jednostki i jej postawy wobec otaczającego ją świata (Siwek 2010). Utrudnieniem w ratowaniu siebie samego/samej jest również lojalność, którą dzieci obdarzają rodziców (Bąbik, Olejniczak 2014). Wiąże się to z przekazem kulturowym, idealizującym rodziców jako darczyńców życia, których należy zawsze szanować, a także z naturalną potrzebą bycia kochana/kochanym i akceptowaną/akceptowanym.

\section{Problem nie istnieje}

Zmierzenie się matki lub ojca z problemami zdrowia psychicznego swojego dziecka jest wymagające zarówno na poziomie poznawczym, jak i emocjonalnym - często jest to sytuacja całkowicie nowa i obca, kojarząca się negatywnie (w dużej mierze także ze stygmatyzacją). Kryzys jednostki okazuje się kryzysem emocjonalnym całej rodziny, cho- 
ciaż doświadczany jest przez jej członków w różny sposób i z różnym natężeniem. Co więcej, dotyczy nie tylko teraźniejszości, lecz i niepewności co do wspólnej (oraz indywidualnej) przyszłości (Frąckowiak-Sochańska 2015). Z tego powodu niektórzy rodzice nie konfrontują się z zaistniałą sytuacją, lecz pojawia się u nich mechanizm wyparcia ${ }^{6}$ lub bagatelizują problemy dziecka poprzez odnoszenie ich do „poważnych problemów dorosłych” (Golus 2018). Jednocześnie jednak nie wychodzą oni poza swoją rolę rodzica, która oceniana jest przez innych uczestników życia społecznego (swoich najbliższych, ale także i chociażby instytucję szkoły), co oznacza, że mogą zapewniać dziecku spełnienie wszelkich potrzeb, niekiedy nawet w celu zagłuszenia pojawiających się problemów, z którymi nie potrafią się skonfrontować (na przykład poprzez drogie prezenty czy rozrywkę).

Wśród powodów, które przyczyniają się do braku wsparcia lub jego iluzorycznej formy, na pewno wymienić należy także brak wiedzy o skutkach zaniedbania zdrowia psychicznego, a także o możliwościach, gdzie można uzyskać pomoc. Nieświadomość ta przyczynia się także do wzmacniania stygmatyzacji osób korzystających z usług psychologa czy psychiatry, rodzice mogą więc obawiać się, że sięgając po pomoc, przyczynią się do pogłębienia problemu swojego dziecka. Z tego powodu konieczność informowania w przekazach medialnych dotyczących tematyki samobójstw o miejscach, gdzie można uzyskać pomoc została zawarta w Deklaracji Uczestników I Kongresu Suicydologicznego, który odbył się

\footnotetext{
6 Wyparcie to jeden $\mathrm{z}$ nieświadomych mechanizmów obronnych, którego zadaniem jest odsunięcie obciążających i bolesnych myśli, wspomnień czy uczuć. Proces ten jest ciągły i utrzymuje te treści poza świadomością jednostki. Pomimo braku ich doświadczania, wypierane bolesne wspomnienia czy uczucia wciąż jednak istnieją, co może przełożyć się z kolei na objawy somatyczne (zob. Poniatowska-Leszczyńska, Zinczuk-Zielazna 2014).
}

w Łodzi w 2018 roku$^{7}$. Niezależnie jednak od tego, czy jednostka w kryzysie doświadcza ze strony swojej rodziny wsparcia pozornego, czy też w ogóle go nie doświadcza, efekt bywa bardzo podobny - pozostaje sama ze swoimi problemami, co wpłynąć może na zanurzanie się $\mathrm{w}$ przekonaniu o przeciążającej sytuacji. W pewnym momencie podjęcie próby samobójczej wydaje się jedynym możliwym wyjściem z sytuacji, co wynika z tunelowego postrzegania swojego położenia i koncentracji na negatywnych wydarzeniach (Koweszko 2019).

Po próbie samobójczej cierpiąca jednostka trafia na oddział do szpitala psychiatrycznego, gdzie ponownie pojawia się zagrożenie pozornego wsparcia w trudnej sytuacji życiowej.

\section{Proces zdrowienia po próbie samobójczej}

Całodobowa opieka na oddziale psychiatrycznym mocno ingeruje $\mathrm{w}$ życie jednostki będącej w kryzysie - po pierwsze, wiąże się z izolacją, po drugie, obowiązują tam ścisłe reguły postępowania i ograniczenia, po trzecie, otoczeniem widywanym każdego dnia stają się inni pacjenci oraz personel medyczny (rodzice/opiekunowie mogą odwiedzać pacjentów, jednak z różnych powodów możliwość ta bywa czasem niewykorzystywana). Doświadczenie hospitalizacji wynikającej ze złej kondycji zdrowia psychicznego jest także kojarzone z późniejszą stygmatyzacją co może napawać lękiem. Jest to

\footnotetext{
${ }_{7}$ Organizatorzy Kongresu: Departament Zdrowia Publicznego Ministerstwa Zdrowia, Zespół Roboczy ds. prewencji samobójstw przy Radzie ds. zdrowia publicznego, Uniwersytet Medyczny w Łodzi, Instytut Psychiatrii i Neurologii w Warszawie, Polskie Towarzystwo Suicydologiczne, Sekcja Naukowa Suicydologii Polskiej Polskiego Towarzystwa Psychiatrycznego oraz Regionalne Centrum Polityki Społecznej - Jednostka Organizacyjna Samorządu Województwa Łódzkiego. Zob. Deklaracja Uczestników I Kongresu Suicydologicznego, http:// konferencjasuicydologiczna.umed.pl/deklaracja-pokongresowa/ (dostęp 30 września 2020 r.).
} 
ostatnia forma pomocy, zazwyczaj wdrażana, gdy jednostka zagraża swojemu własnemu życiu albo zdrowiu/życiu innych osób - wówczas nie jest konieczne skierowanie lekarskie, podobnie jak i zgoda pacjenta (Zalewska-Łunkiewicz 2016). Rodzice lub opiekunowie prawni mogą wystąpić o wypis dziecka z oddziału psychiatrycznego, jednak lekarz może odmówić wypisania pacjenta, jeśli jego stan nie jest wystarczająco ustabilizowany. Wówczas rodzice mają prawo skierować sprawę do sądu opiekuńczego, gdzie rozstrzyga się o słuszności decyzji lekarza. Co ważne, hospitalizacja jest skutkiem podjęcia próby samobójczej lub wyraźnym zamiarem jej realizacji (np. przygotowanie listu pożegnalnego, opracowanie planu działania, przygotowanie potrzebnych narzędzi lub środków). Natomiast pojawiające się myśli rezygnacyjne lub samookaleczenia mające na celu redukcję napięcia nie są bezwzględnym wskazaniem do hospitalizacji, a raczej do interwencji, polegającej przede wszystkim na wizycie u odpowiedniego specjalisty (Chatizow 2018).

$\mathrm{W}$ procesie leczenia psychoterapia powinna być połączona z konsultacjami psychiatrycznymi i farmakoterapią - taką pomoc można jednak zazwyczaj otrzymać dopiero na oddziale (jeśli nie jest on przeciążony). W ten sposób próbuje się ustabilizować stan młodego pacjenta oraz wypracowuje się z nim techniki rozładowania napięcia i strategie radzenia sobie z problemami bez uciekania się do autodestrukcyjnych zachowań. Warto jednak podkreślić, że w przypadku hospitalizowanych dzieci i młodzieży terapeuta nie jest postrzegany jako "swój” - należy bowiem do świata dorosłych, a często to dorośli przyczyniają się do problemów młodej jednostki lub nie rozumieją i bagatelizują przeżywane przez nią emocje. Podmiotowość młodej osoby jest tu zagrożona podwójnie - stawiana jest w pozycji nie tylko pacjenta, wobec którego terapeuta ma po- zycję nadrzędną wynikającą z charakteru interakcji, ale do tego jest pacjentem niepełnoletnim. Stanowi to dodatkową barierę w relacji terapeutycznej, która jest częścią procesu leczenia po próbie samobójczej (Makara-Studzińska 2017).

W sytuacji, gdy proces leczenia zostaje uznany za zakończony, to jest osoba hospitalizowana nie wykazuje już tendencji samobójczych, a jej zachowanie i codzienne funkcjonowanie nie wskazują na możliwość stwarzania stanu zagrożenia dla samej siebie, zostaje wypisana z oddziału szpitala psychiatrycznego.

Objęcie procesem leczenia jednostki po próbie samobójczej wydaje się więc zdecydowanie niewystarczające, jeżeli najbliższe otoczenie postrzegane jest przez nią jako główna przyczyna (lub jedna z przyczyn) kryzysu. Podjęcie przez nią kolejnych prób, wśród których może znaleźć się również ta zakończona zgonem, staje się wówczas bardziej prawdopodobne, nie znika bowiem bodziec jawiący się jako przeciążająca przeszkoda. W przypadku „twardych” wskaźników dysfunkcjonalności rodziny zastosować można pewne rozwiązania prawne, ponieważ krzywda dziecka często jest widoczna i niezaprzeczalna. Jednak w przypadku wskaźników „miękkich” nie można egzekwować zmian u rodziców dziecka/nastolatka hospitalizowanego po próbie samobójczej, a same ich skutki w sposób wyraźny potrafią uwidocznić się dopiero, gdy staje się on osobą dorosła, podejmującą własne decyzje i nawiązującą relacje. Niekiedy zdrowiejące dzieci czy młodzież zgłaszają powrót myśli samobójczych, gdy nadchodzi czas zakończenia hospitalizacji. Lęk przed zbliżającym się powrotem do własnego domu potrafi poniekąd wymazać dokonane w ramach leczenia postępy. Odebranie praw rodzicielskich czy nakaz (efektywnego) uczestniczenia w procesie terapii rodzinnej nie są jednak możliwe z przyczyn 
tak niemierzalnych. Jednocześnie skrajne oczekiwania rodziców (zarówno te zbyt wysokie, jak i zbyt niskie), destrukcyjne relacje pomiędzy rodzicem a dzieckiem czy nawet nadmierna kontrola wskazywane są jako czynniki suicydogenne z kategorii czynników rodzinnych, obok rozwodu rodziców, ich uzależnienia od substancji psychoaktywnych czy nawet dokonywanego przez nich molestowania dziecka (Sumiła, Sulska 2006).

Samobójstwo nie jawi się jako problem sam w sobie, jest bowiem reakcją jednostki na przeciążającą dla niej sytuację życiową (Zwoliński 2013). Omawiane zjawisko jest jednak istotne z perspektywy nie tylko powodu, lecz i rzeczywistego celu. Przedstawiona tabela (zob. Tabela 1) dotycząca prób samobójczych oraz samobójstw zakończonych zgonem wśród dzieci i młodzieży stanowi ilustrację głoszonego przez suicydologów wniosku, iż często celem prób samobójczych w tej grupie wiekowej nie jest śmierć, lecz dostarczenie znaczącym innym komunikatu o swoim cierpieniu (Sumiła, Sulska 2006). Niekiedy werbalne komunikowanie czy też inne znaki (np. wycofanie się z kontaktów rówieśniczych, niższe oceny, drażliwość) bywają niezauważone czy też nawet lekceważone przez najbliższe otoczenie. Chciałoby się rzec, że nie da się nie dostrzec cierpienia dziecka lub nastolatka, któremu udaje się przeżyć próbę samobójczą i przed którym jest cały proces zdrowienia i powrotu do wewnętrznej równowagi. Niestety, nie dla wszystkich jest to ciąg przyczynowo-skutkowy wywołujący właściwe reakcje, czemu częściowo winny jest tworzony system.

\section{Za fasadą - pozorność działań w procesie zdrowienia}

Peter L. Berger (1997), pisząc o świadomości socjologicznej, akcentował przede wszystkim patrzenie za tak zwane fasady przejawiające się w oficjalnych komunikatach oraz uwzględnianie konkurencyjnych interpretacji danego zjawiska społecznego. Socjologia w tym rozumieniu mówi „sprawdzam” wobec funkcjonującego systemu, konfrontując jego założenia z rzeczywistymi działaniami. I chociaż Berger (Berger, Luckmann 1983; Berger 1997) wskazuje na konstruowane społecznie systemy znaczeniowe tworzące uniwersum, to stawia socjologię poniekąd ponad nimi (a już na pewno ponad systemową rolą psychologii i terapii). Według niego terapia jest pewną formą kontroli społecznej, której zadaniem jest zatrzymanie jednostek $\mathrm{w}$ ramach danego uniwersum, co możliwe jest poprzez opracowanie specjalistycznego systemu pojęć, zatwierdzonego przez ekspertów i prowadzącego do internalizacji przez jednostkę otrzymanej diagnozy, która „stanie się dla niej subiektywnie rzeczywista”" (Berger, Luckmann 1983: 181). Natomiast w przypadku socjologii tworzenie własnego aparatu pojęciowego jest ucieczką przed słownictwem potocznym, które może być niejednoznaczne i mylące - w tym samym miejscu pojawia się również teza, iż każda dyscyplina posiada własną terminologię (Berger 1997). Pewien brak konsekwencji ujawnia się również w odniesieniu do rzekomej obiektywności i opisywaniu rzeczy „takimi, jakimi się mają" poprzez dążenie do aktu czystej percepcji (Berger 1997: 15) - jednak czyż nazywanie odkryć w ramach terapii „wymysłami” czy porównanie tejże praktyki z działaniami specjalisty od „prania mózgów” (Berger 1997: 66) rzeczywiście jest zaledwie opisem?

Podobnie jak $\mathrm{w}$ przypadku systemu rodzinnego, ponownie nasuwa się tutaj koncepcja działań pozornych Lutyńskiego. Na ich występowanie w sektorze pomocy społecznej wielokrotnie wskazywała Dobroniega Trawkowska (2007; 2009) - począwszy od fikcyjnych programów włączających, przez nie- 
istniejącą współpracę pomiędzy specjalistami, aż po pozorne rozwiązywanie problemów społecznych. Pozorność podnoszono również w temacie stanowienia prawa (Kubiak, Krzewińska 2009) czy szeroko rozumianej edukacji, $\mathrm{w}$ tym jej ewaluacji, która prezentowana $\mathrm{w}$ celach wizerunkowych nie wnosi żadnych realnych rozwiązań (Parys 2014; Kochanowska 2017; Groenwald 2019). Jednocześnie należy wspomnieć, iż pracując w systemie, którego jeden z filarów jest doskonałą ilustracją działania pozornego, można pełnić wobec niego różne funkcje - oznacza to, że można być jego współtwórcą, lecz także i jego „ofiarą” (Trawkowska 2009). Powielanie działań pozornych nie musi być bowiem tożsame z ich akceptacją - niekiedy postępowanie to bywa mocno zinternalizowane przez jednostkę, a jego pozorność nie jest uświadomiona lub pewne czynniki (np. nadzieja na zmiany czy zagrożenie utratą pracy) zatrzymują człowieka w określonych ramach systemowych. Jakie konkretnie warunki mogą przyczyniać się do występowania iluzorycznych działań w ramach całodobowej opieki psychiatrycznej?

\section{Brak rozwiązań systemowych}

Akcje psychoedukacyjne czy kampanie społeczne dotyczące zdrowia psychicznego podejmowane są oddolnie, przez specjalistów i osoby z zaburzeniami lub chorobami psychicznymi, a skierowane są do innych profesjonalistów, a także szerzej - do społeczeństwa oraz organów władzy. W ramach warszawskiego II Kongresu Zdrowia Psychicznego, który odbył się w czerwcu 2019 roku, podpisana została Deklaracja Warszawska zawierająca najważniejsze postulaty środowisk psychiatrycznych i psychologicznych w celu poprawienia warunków zapewnianej opieki. Jednym z głównych aspektów jednostronicowego dokumentu było zwrócenie uwagi na niewłaściwe rozwiązania systemowe:

[żądamy] zasilenia systemowej zmiany $\mathrm{w}$ ochronie zdrowia psychicznego adekwatnymi środkami finansowymi, usunięcia wieloletniej tolerancji dla jaskrawej nierówności i błędów w finansowaniu i inwestowaniu w tej dziedzinie - nakłady na ochronę zdrowia psychicznego powinny bezzwłocznie osiągnąć co najmniej średni w Europie (5-6\%) udział wśród ogółu wydatków na zdrowie; szacunkowo wymaga to zwiększenia o 2/3 wydatków w populacji dorosłych i ich podwojenia w populacji dzieci i młodzieży łącznie, w przybliżeniu o nie mniej niż 1 miliard złotych. (Deklaracja Warszawska II Kongresu Zdrowia Psychicznego)

Znajdujemy się obecnie $\mathrm{w}$ sytuacji wzajemnego obarczania winą - rodzice obwiniają specjalistów, specjaliści rodziców i osoby zarządzające, osoby zarządzające polityków. I każdy z tych podmiotów ma trochę racji. Nie oznacza to, że któryś z nich powinien dźwigać tę odpowiedzialność sam, żaden z nich nie może również całkowicie pozbyć się jej ze swoich barków. Mimo to żaden rodzic, żaden psycholog, terapeuta czy psychiatra nie wprowadzą rewolucyjnych (i koniecznych) zmian bez odpowiednich regulacji prawnych i finansowych ustalanych na poziomie systemu. Zwłaszcza, gdy pod uwagę wziąć społeczny wymiar definiowania chorób oraz postępujące upowszechnianie leczenia farmakologicznego jako rozwiązania szybszego i łatwiej dostępnego niż długotrwała i wymagająca terapia czy nawet psychoedukacja (Wróblewski 2012; 2016; Mills 2018; Witeska-Młynarczyk 2018). Środowisko psychiatryczne apeluje więc o deinstytucjonalizację obecnego systemu i wprowadzenie modelu środowiskowego, który zapewni nie tylko dostęp do wła- 
ściwego leczenia, ale i możliwość jego odbywania w odpowiednich warunkach ${ }^{8}$.

\section{Brak środków finansowych na szkolenie kadry}

Szkolenia prowadzone przez specjalistów z danej dziedziny zazwyczaj przekraczają przeciętny próg możliwości finansowych osób zainteresowanych, szczególnie jeśli nie mogą one liczyć na finansowe wsparcie niedoinwestowanych placówek ich zatrudniających. Koszt jednodniowego szkolenia z interwencji kryzysowej organizowanej przez Polskie Towarzystwo Suicydologiczne to około $600 \mathrm{zł}$ brutto $^{9}$, a opłata za dwa semestry podyplomowych studiów na kierunku psychologia kryzysu i interwencji kryzysowej na jednej z najlepszych polskich uczelni psychologicznych - SWPS Uniwersytet Humanistycznospołeczny ${ }^{10}$ - wynosi ponad 8 tysięcy złotych $^{11}$. Oddziały psychiatryczne nie posiadają do dyspozycji takich środków finansowych, by opłacać swojej kadrze kursy i szkolenia pozwalające zdobywać nową i aktualną wiedzę oraz rozwijać kompe-

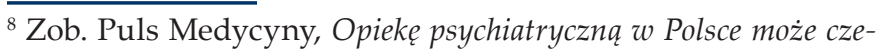
kać zapaść, konieczne sa dalsze działania reformacyjne. List psychiatrów do ministra zdrowia, https://pulsmedycyny.pl/opiekepsychiatryczna-w-polsce-moze-czekac-zapasc-konieczne-sadalsze-dzialania-reformacyjne-list-psychiatrow-do-ministrazdrowia-1003509?fbclid=IwAR3V49oF-VsabFA3RnfNcwzhWyQAKOP1uoHwDznzrEIxHtEWCEfqYE9mn5s (dostęp 29 września 2020 r.).

9 Zob. Polskie Towarzystwo Suicydologiczne, https://suicydologia.org/samobojstwo-i-proba-samobojcza-interwencjakryzysowa-w-sytuacji-zagrozenia-zycia/ (dostęp 16 maja 2020 r.).

${ }^{10}$ Zgodnie z parametryzacją jednostek naukowych w 2017 roku najwyższą kategorię A+ dostały trzy psychologie, z czego dwie w ramach SWPS:

(1) SWPS Uniwersytet Humanistycznospołeczny z siedzibą w Warszawie; Wydział Psychologii,

(2) SWPS Uniwersytet Humanistycznospołeczny z siedzibą w Warszawie; Filia we Wrocławiu; II Wydział Psychologii,

(3) Uniwersytet Warszawski; Wydział Psychologii.

${ }^{11}$ Zob. SWPS Uniwersytet Humanistycznospołeczny, https:// www.swps.pl/oferta/warszawa/podyplomowe/psychologia-psychoterapia/psychologia-kryzysu-i-interwencji-kryzysowej (dostęp 16 maja 2020 r.).
}

tencje $\mathrm{w}$ zakresie pracy z pacjentem. W planie finansowym NFZ na rok 2019 (z uwzględnieniem zmian zatwierdzonych 5 czerwca 2019) koszty wynosiły ponad 93 mld złotych, z czego na opiekę psychiatryczną i leczenie uzależnień przeznaczono łącznie niewiele ponad 3 mld złotych, stanowiących 3,2\% całej sumy (Ministerstwo Zdrowia 2019).

\section{Niewielka liczba specjalistów wobec skali zjawiska}

Spośród 169287 lekarzy w Polsce specjalistów w dziedzinie psychiatrii dzieci i młodzieży jest zaledwie 491, zawód wykonuje natomiast $455^{12}$ (Naczelna Izba Lekarska 2020). Liczbę lekarzy psychiatrów warto podawać w odniesieniu do wielkości populacji - w Polsce na 100 tys. mieszkańców przypadało w 2017 roku nieco ponad 9 psychiatrów; dla porównania w Grecji było to ponad 25 psychiatrów, a w Niemczech ponad 27. W statystykach obejmujących kraje przynależące do Unii Europejskiej mniejszą liczbę psychiatrów w stosunku do 100 tys. mieszkańców miała jedynie Bułgaria - tutaj wskaźnik ten wynosił 7,7 (Eurostat 2017). Zdecydowana większość $\mathrm{z}$ nich prowadzi prywatną praktykę $\mathrm{w}$ gabinecie, natomiast część jest również zatrudniona na oddziałach psychiatrycznych, na etacie lub w ramach kontraktu (co z kolei zmusza do przemieszczania się między różnymi oddziałami i klinikami, niekiedy nawet $\mathrm{w}$ ramach jednej doby). Do tego mierzymy się także z ogromnym zróżnicowaniem terytorialnym $\mathrm{w}$ dostępie do leczenia psychiatrycznego. Według najnowszego raportu Najwyższej Izby Kontroli w 2019 roku w Polsce funkcjonowało 40 stacjonarnych oddziałów psychiatrycznych dla dzieci i młodzieży oraz 46 oddziałów dziennych dla osób poniżej osiemnastego roku życia. Jednocześnie żaden

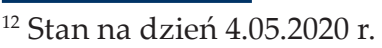


z oddziałów stacjonarnych nie znajdował się w województwie podlaskim, w sąsiednim województwie warmińsko-mazurskim nie było natomiast oddziału dziennego, podobnie jak i w województwie zachodnio-pomorskim, lubuskim, opolskim i świętokrzyskim (Najwyższa Izba Kontroli 2020).

Praca na oddziale to zmierzenie się z pacjentami, którzy są w poważnym kryzysie lub ich choroba zagraża im samym lub osobom w otoczeniu - oznacza to naprawdę dużą odpowiedzialność. Brakuje natomiast specjalistów, których można byłoby uwzględnić przy planowaniu dyżurów - według danych zebranych przez Sieć Obywatelską Watchdog Polska na jedno szpitalne łóżko przypada około 0,1 etatu psychiatry ze specjalizacją psychiatrii dzieci i młodzieży (Bójko, Maślankiewicz 2020). Bywają także okresy, w których szpitale przyjmują zdecydowanie większą liczbę pacjentów niż było to przewidziane. O przekroczeniu limitu i przyjmowaniu pacjentów na „dostawki” głośno było przede wszystkim na oddziałach w Gdańsku oraz Józefowie (Suchodolska 2018; Palińska 2019), gdzie przeciążony i przemęczony personel złożył wypowiedzenia, nie chcąc odpowiadać za brak możliwości zabezpieczenia opieki psychiatrycznej i psychologicznej dla tychże pacjentów. Jest to jednak codzienność wielu miast w Polsce.

\section{Brak psychologicznego wykształcenia znacznej części kadry}

W przypadku szpitali psychiatrycznych, używając określenia „zespół” lub „kadra”, mamy zazwyczaj na myśli psychiatrów oraz psychoterapeutów lub psychologów. Jednak ich wymiarem pracy jest zazwyczaj pełny etat - 40 godzin tygodniowo, czyli 8 godzin dziennie. Oznacza to, że na oddziale całodobowym przez pozostałe 16 godzin opiekę nad pacjentem sprawują pielęgniarki i pielęgniarze oraz ratowniczki i ratownicy. Personel ten nie ma obowiązku posiadania wykształcenia psychologicznego, nie organizuje się również odpowiednich szkoleń wprowadzających w specyfikę pracy w szpitalu psychiatrycznym, gdzie przebywają pacjenci z różnymi chorobami lub zaburzeniami psychicznymi. U niektórych z nich może pojawić się agresja (zarówno słowna, jak i fizyczna), dlatego personel szkolony jest z prowadzenia interwencji, która wiąże się z unieruchomieniem, a czasem izolacją (Kupś, Pełka-Wysiecka, Samochowiec 2007). Agresja wynika jednak niekiedy z braku posiadania konstruktywnej strategii radzenia sobie ze stresem lub trudnymi emocjami. Natomiast odpowiednia postawa personelu medycznego, oparta przede wszystkim na empatii oraz wsparciu, jest jednym z czynników chroniących przed powtórzeniem próby samobójczej (Gmitrowicz, Krawczyk 2014).

\section{Biurokratyzacja i brak przestrzeni na wprowadzanie nowych rozwiązań}

Nie budzi wątpliwości, że szpitale pozostają instytucjami wysoko sformalizowanymi i biurokratycznymi - dotyczy to również oddziałów psychiatrycznych, posiadających jasno sprecyzowaną hierarchię oraz podział ról, których prawidłowe wykonywanie jest szczegółowo określone w dokumentach szpitala oraz w Ustawie o ochronie zdrowia psychicznego z dnia 19 sierpnia 1994 roku. Jednostkowe próby wprowadzenia innowacyjnych metod z góry skazane są więc na niepowodzenie (przez co zazwyczaj nawet nie są podejmowane), ponieważ wykraczają poza te zapisy (Stasiuk-Krajewska 2014).

Wsparcie instytucjonalne, z powodu zbyt niskiego finansowania oraz niewystarczającej liczby profesjonalistów, często nie dysponuje odpowiedni- 
mi zasobami, by $\mathrm{w}$ procesie zdrowienia młodego człowieka uwzględnić również jego rodziców lub opiekunów. Tymczasem psychoterapia rodzinna postrzegana jest jako czynnik wpływający na obniżenie prawdopodobieństwa podjęcia kolejnej próby samobójczej (Makara-Studzińska 2017). Relacje w rodzinie charakteryzujące się ciepłem, zaufaniem i wyrozumiałością umożliwiają dziecku wzrastanie w zdrowych warunkach, co pozytywnie wpływa na jego kształtującą się tożsamość (Radoń, Samochowiec 2017). Jednak pomimo badań i podejmowanych przez specjalistów dyskusji, system nie posiada żadnych instrumentów, by mogło to zostać uznane za obowiązkowy i kluczowy element wyzdrowienia młodej jednostki. W trudnych sytuacjach lekarz psychiatra, psychoterapeuta lub psycholog może zaprosić rodziców na konsultacje rodzinne, których nie należy jednak utożsamiać $\mathrm{z}$ terapią rodzinną. Podejmowane działania mają służyć leczeniu i poprawie zaistniałej sytuacji, natomiast $\mathrm{w}$ rzeczywistości tworzą jedynie pewną fasadę ochronną dla systemu. W przypadku kolejnej próby samobójczej odpowiedzialność przesuwa się więc na cierpiącą jednostkę, której przypadek był „zbyt trudny”. Natomiast dla części młodych osób po próbie samobójczej leczenie na oddziale psychiatrycznym jest raczej chwilowym azylem niż końcowym etapem na ścieżce do uzyskania równowagi zdrowia psychicznego. W ramach reformy psychiatrii rozpoczęto w 2018 roku trzyletni program pilotażowy w centrach zdrowia psychicznego, którego celem jest zwiększenie dostępności opieki specjalistów oraz dezinstytucjonalizacja leczenia psychiatrycznego na rzecz leczenia środowiskowego, pozbawionego elementu izolowania pacjenta. Pilotaż ten obejmuje jednak osoby, które ukończyły 18 lat ${ }^{13}$.

${ }_{13}$ Zob. Centrum Z drowia Psychicznego, https://czp.org.pl/ (dostęp 19 lipca 2020 r.).
Nasuwać się tutaj może również koncepcja działań neopozornych, zakładająca niewiedzę zarówno po stronie prywatnej, jak i publicznej (Czyżewski 2009), jednak działania podejmowane oddolnie przez specjalistów oraz pacjentów czy ich rodziców wydają się nie spełniać tego warunku. Znaczna część artykułów pojawiająca się w dyskursie medialnym $\mathrm{w}$ ramach tego tematu przyjmuje formułę rozmowy z psychiatrą czy psychologiem pracującym na konkretnym oddziale i alarmującym o bieżącej sytuacji, co wyklucza brak samoświadomości czy autorefleksji będącej główną cechą działań neopozornych (chociaż $\mathrm{w}$ tym rozumieniu jako działania neopozorne można byłoby wskazać działania władzy, która nie tyle tworzy fasadowość, co rzeczywiście wydaje się nie interesować tym tematem mimo opierania na nim swoich haseł politycznych, tj. podtrzymywania uniwersum).

\section{Podsumowanie}

Zgodnie $\mathrm{z}$ narracją prowadzoną $\mathrm{w}$ polskich mediach oraz polityce rodzina jest podstawową wartością, na której powinna koncentrować się znaczna część działań planowanych na poziomie makrospołecznym, i na których, rzekomo, opiera się system, dążąc do poprawy sytuacji rodzin $\mathrm{w}$ całym kraju. Pozorność ta ujawnia się jednak bezpośrednio w systemowych rozwiązaniach, a chociaż zawarte $\mathrm{w}$ artykule spojrzenie dotyczy zaledwie jednego aspektu - rodziny jako czynnika suicydogennego to ilustruje jak dużo procedur i czynności musi jeszcze zostać wdrożonych. Miłość rodzicielska i prawidłowa socjalizacja (zakładająca niewyrządzanie krzywdy innym oraz sobie) są pewnego rodzaju wentylem bezpieczeństwa dla młodej osoby będącej w procesie adaptacji do życia w społeczeństwie. Ich funkcjonalność ma więc wymiar poniekąd przekrojowy, ponieważ nie dotyczy zaledwie wycinka 
rzeczywistości, lecz rzutuje na całą perspektywę przyjmowaną przez jednostkę. I chociaż według statystyk i literatury naukowej problem ten istniał już od wielu lat, to dopiero niedawne nagłośnienie w dyskursie medialnym danych z 2014 roku, według których zajmujemy drugie miejsce pod względem samobójstw dzieci i młodzieży w Europie (Fundacja Dajemy Dzieciom Siłę 2017), wskazało, iż nasze uniwersum jest zagrożone. Polityka presuicydalna oraz uwarunkowania kulturowe w wielu innych krajach okazują się bowiem skuteczniejsze, co podaje w wątpliwość słuszność definiowania przez nas rzeczywistości, zwłaszcza tej dotyczącej systemu rodzinnego, ujawniając przynoszącą pozytywne rezultaty alternatywę i zakłócając funkcjonujący, choć nieefektywny, porządek (Berger, Luckmann 1983).

Człowiek jest nie tylko samodzielnym, indywidualnym bytem $\mathrm{z}$ własnymi procesami psychicznymi, ale także (lub być może przede wszystkim) osadzony jest $\mathrm{w}$ ramach systemu rodzinnego, który niezależnie od formy może mieć duży wpływ na jego myślenie, emocje oraz działania. Często problemy jednostki są wręcz reprezentacją nieprawidłowości w relacjach między członkami najbliższej rodziny. Rodzice kształtują dziecko, socjalizując je zgodnie z przyjętymi przez siebie (w sposób mniej lub bardziej uświadomiony) wzorami i normami. W rodzinie, gdzie dzieci jest więcej niż jedno, pojawiają się jeszcze inne wpływy i powiązania, takie jak wspólnota genów czy historii rodzinnej - by terapia rodzinna została $\mathrm{w}$ pełni przeprowadzona, powinna również uwzględniać rolę rodzeństwa i włączać je do procesu (Namysłowska, Siewierska 2009). Wówczas terapia pozwala nie tylko zidentyfikować obszar do zmiany, lecz także odkryć potencjał tkwiący w rodzinie i posiadanych przez nią zasobach. Jako zasoby rodzinne rozumiane są tutaj zarówno te indywidualne, posiadane przez każdego członka da- nej rodziny, jak i ich wspólne metody radzenia sobie w trudnych sytuacjach czy, szerzej mówiąc, system wsparcia w ramach ich własnej struktury (Kulesza 2015). Od relacji w rodzinie zależy bowiem, czy będzie ona pełnić rolę czynnika chroniącego przed samobójstwem, czy wręcz przeciwnie - stanie się decydującym czynnikiem ryzyka (Ziółkowska 2016).

I chociaż można byłoby tu odwołać się do indywidualnych predyspozycji oraz posiadania własnych zasobów, które mogą być pomocne w „przetworzeniu" pewnych trudności czy podejmowaniu słusznych decyzji, to nie da się ukryć, że jednostka, która już na początku życia funkcjonuje wśród negatywnych wzorów zachowań i nieprawidłowych relacji, będzie znać zupełnie inne sposoby na pełnienie roli dziecka, a następnie matki czy ojca, niż te zakładane i uznawane za „zdrowe”. Obciążenie na tym podstawowym poziomie kształtowania się człowieka ma więc kluczowy wpływ zarówno na niego samego, jak i jego otoczenie. Gdy nastąpi kumulacja problemów i czynników stwarzających zagrożenie, brak wsparcia ze strony znaczących innych może przyczynić się do decyzji o zakończeniu swojego cierpienia poprzez odebranie sobie życia. Jednocześnie należy pamiętać, że na jednostkę oddziałuje więcej niż jeden czynnik suicydogenny - istotne są więc związki pomiędzy tymi składowymi, ponieważ wpływają one na siebie wzajemnie (Gmitrowicz $i$ in. 2015). Biorąc pod uwagę, iż rodzina może istotnie przechylić szalę tej decyzji, powinno się podejmować efektywne działania skierowane do ogółu społeczeństwa, a nie tylko do jednostek w kryzysie.

Alice Miller (1999) uznała, że dziecko, wobec którego rodzic okazuje wyraźnie swoją nadrzędną pozycję władzy poprzez bicie czy wymuszanie posłuszeństwa i znoszenie upokarzających kar, jest "duchowo zabijane”. I chociaż głównie odnosiła się 
do tego, iż doświadczając takich przeżyć w dzieciństwie, jednostka internalizuje to jako sposób komunikowania się i budowania swojej pozycji, przez co sama staje się oprawca, to wskazywała również, że przede wszystkim prowadzi to do jej autodestrukcji. Poniższy cytat oddaje sens i znaczenie problemu popełniania przez dzieci i młodzież prób samobójczych wywołanych przeciążającym cierpieniem $\mathrm{w}$ ramach relacji rodzinnych:

Kiedy się dziecko wychowuje, uczy się je wychowywać. Kiedy prawi się mu morały, uczy się ono prawić morały, kiedy się mu wymyśla, uczy się wymyślać, kiedy się je wykpiwa, uczy się wykpiwać, kiedy się je upokarza, uczy się upokarzać, kiedy się je duchowo zabija, uczy się zabijać. Pozostaje mu tylko do wyboru, czy zabijać siebie, czy innych, czy też i siebie, i innych. (Miller 1999: 116)

Przyjęte w leczeniu dzieci i młodzieży rozwiązania systemowe (mimo całego wysiłku psychiatrów, psychologów i psychoterapeutów) są niczym plaster naklejony na złamaną nogę. Chociaż będzie on wytrzymały, elastyczny czy wodoodporny, nie uleczy uszkodzonej kości i pod tym względem można tutaj zastosować koncepcję działań pozornych Jana Lutyńskiego. Szybkie wdrażanie środków farmakologicznych od najmłodszych lat, często bez równolegle prowadzonej terapii (a raczej zamiast niej), nie jest rozwiązaniem, lecz łagodzeniem objawów (Wróblewski 2012; 2016; Witeska-Młynarczyk 2018). Natomiast rzeczywistym środkiem zaradczym powinno być prawdziwe wspieranie rodziny, począwszy od lepszej ochrony bezbronnych dzieci przed przejawami "twardej” dysfunkcjonalności, po cały zestaw odpowiednich rozwiązań $\mathrm{w}$ przypadku wskaźników „miękkich”, opracowanych przez specjalistów i wdrażanych z poziomu systemu (w tym psychoedukacji już na pierwszych szczeblach na- uki), czego zaproponowanie na łamach niniejszego artykułu przekracza moje kompetencje. Natomiast podejmowanie badań $\mathrm{w}$ myśl bergerowskiego zaglądania za fasadę wydaje się słusznym krokiem do pełnej eksploracji obszaru zachowań samobójczych dzieci i młodzieży. Zwłaszcza, jeśli badania te prowadzone będą w oparciu o współpracę badaczy z różnych dyscyplin - kluczowe wydaje się tu korzystanie z osiągnięć socjologii i psychiatrii, o którym wspomina Witeska-Młynarczyk (2018), ale także pedagogiki czy psychologii. Podobnie jak docenianie badań zarówno ilościowych, jak i jakościowych, które wspólnie uzupełniają znaki zapytania (Ziółkowska 2016). Pozwoli to na utrzymanie rzeczywistej, a nie iluzorycznej podmiotowości dzieci i młodzieży, a także, miejmy nadzieję, przyczyni się do podejmowania merytorycznych dyskusji w dyskursie politycznym oraz do opracowywania skutecznych rozwiązań systemowych w celu zapewnienia młodym jednostkom odpowiednich warunków do leczenia czy konstruktywnego radzenia sobie z doświadczanym kryzysem.

Problem zachowań samobójczych wśród osób młodych jest bardzo złożony, w niniejszym artykule skoncentrowano się zaledwie na pewnym wycinku tego zjawiska. Tytułowa „niemiłość” odnosi się do braku tego konkretnego rodzaju miłości w rodzinie, który pozwala młodej jednostce wzrastać w poczuciu akceptacji, ciepła i przynależności oraz prawidłowo tworzyć tożsamość i zdolność do funkcjonowania w społeczeństwie ${ }^{14}$. Żadna instytucja, także ta zajmująca się zdrowiem psychicznym, nie jest w stanie dostarczyć tego jednostce $\mathrm{w}$ takim wymiarze jak jej najbliższe otoczenie. Stoimy natomiast obecnie $\mathrm{w}$ obliczu sytuacji, gdy

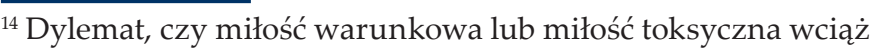
jest miłością pozostawiam więc poza tym artykułem, temat ten wymaga bowiem znacznie więcej uwagi niż jeden akapit.
} 
nawołuje się do ponownego odebrania dzieciom praw do własnych emocji, opinii, decyzji i ciała na rzecz kompletnej władzy rodzicielskiej. Poprzednie pokolenia dorastały jednak w zupełnie innych warunkach społecznych, ekonomicznych, politycznych, a także technologicznych. Wachlarz możliwości był zdecydowanie mniejszy, podobnie jak i dostęp do wiedzy - można przypuszczać, że system wartości rodziców częściej był powielany niż kwestionowany. Obecnie dla części młodych jednostek decyzje czy alternatywne wybory są widoczne, jednak znajdują się poza ich zasięgiem. $\mathrm{Na}$ wyciągnięcie ręki jest natomiast decyzja o zakończeniu swojego życia, a także opakowanie leków, żyletka, kuchenny nóż czy płyn do udrażniania rur...

\section{Bibliografia}

Badora Sylwia (2011) Miłość rodzicielska - reguła czy przypadek? Studium antropologiczne. „Pedagogika Rodziny”, t. 1, nr 1, s. 41-56.

Bąbik Aleksandra, Olejniczak Dominik (2014) Uwarunkowania i profilaktyka samobójstw wśród dzieci i młodzieży w Polsce. „Dziecko Krzywdzone. Teoria, badania, praktyka", t. 13, nr 2, s. 99-121.

Berger Peter L. (1997) Zaproszenie do socjologii. Przełożył Janusz Stawiński. Warszawa: Wydawnictwo Naukowe PWN.

Berger Peter L., Luckmann Thomas (1983) Społeczne tworzenie rzeczywistości. Przełożył Józef Niżnik. Warszawa: Państwowy Instytut Wydawniczy.

Bójko Martyna, Maślankiewicz Roksana (2020) Sytuacja w polskiej psychiatrii dziecięcej na przełomie lat 2018 i 2019 na podstawie danych zebranych w trybie dostepu do informacji publicznej. „Dziecko Krzywdzone. Teoria, badania, praktyka", t. 19, nr 1, s. 116-154.

Chatizow Joanna (2018) Depresja i samobójstwa dzieci i młodzieży. Żyć, nie umierać - poradnik dla rodziców i nauczycieli. Warszawa: Difin SA.

Czarnek Przemysław (2018) Konstytucyjnoprawna ochrona dziecka [w:] Alicja Grześkowiak, Igor Zgoliński, red., Prawo karne w ochronie praw dziecka. Bydgoszcz: Wydawnictwo Kujawsko-Pomorskiej Szkoły Wyższej w Bydgoszczy, s. 9-21.

Czyżewski Marek (2009) „Działania neopozorne”. Uwagi na temat przeobrażeń komunikowania publicznego i życia naukowego. „Przegląd Socjologiczny", t. 58, nr 1, s. 9-31.
Deklaracja Warszawska II Kongresu Zdrowia Psychicznego [dostęp 20 kwietnia 2020 r.]. Dostępna w Internecie: https:// kongreszp.org.pl/wp-content/uploads/sites/2/2019/06/Deklaracja-Warszawska-II-Kongresu.pdf).

Durkheim Émile (2011) Samobójstwo. Studium z socjologii. Przełożył Krzysztof Wakar. Warszawa: Oficyna Naukowa.

Eurostat (2017) Physicians by medical speciality [dostęp 5 lipca 2020 r.]. Dostępny w Internecie: ‘https://appsso.eurostat.ec.europa.eu/nui/submitViewTableAction.do».

Frąckowiak-Sochańska Monika (2015) Poznawcza i emocjonalna adaptacja do sytuacji choroby psychicznej w rodzinie. „Przegląd Socjologii Jakościowej", t. 11, nr 4, s. 88-112.

Frączek Zofia (2019) Rodzina wobec przemian społecznych. O wychowawczym funkcjonowaniu rodziny i możliwościach jego doskonalenia. „Kultura - Przemiany - Edukacja”, t. 7, s. 69-80.

Fundacja Dajemy Dzieciom Siłę (2017) Dzieci się liczą 2017. Raport o zagrożeniach bezpieczeństwa i rozwoju dzieci w Polsce [dostęp 20 kwietnia 2020 r.]. Dostępny w Internecie: 〈https://fdds.pl/wp-content/uploads/2017/07/fdds-dzsl2017-calosc.pdf».

Fundacja Dajemy Dzieciom Siłę (2018) Ogólnopolska diagnoza skali $i$ uwarunkowań krzywdzenia dzieci. Raport z badań [dostęp 20 kwietnia 2020 r.]. Dostępny w Internecie: https://fdds.pl/ wp-content/uploads/2018/12/Og\%C3\%B3lnopolska-diagnozaskali-i-uwarunkowa\%C5\%84-krzywdzenia-dzieci_Wyniki-badania_2018.pdf). 
Gmitrowicz Agnieszka, Krawczyk Joanna (2014) Analiza czynników chroniacych przed samobójstwem. „Psychiatria i Psychologia Kliniczna", t. 14, nr 1, s. 43-49.

Gmitrowicz Agnieszka i in. (2015) Motywy podejmowania prób samobójczych przez młodzież w wieku 13-19 lat. "Journal of Education, Health and Sport", vol. 5, no. 6, s. 51-64.

Golus Anna (2018) Od przedmiotu do podmiotu. Status dziecka w rodzinie i społeczeństwie. „Studia Edukacyjne”, nr 48, s. 315-334.

Groenwald Maria (2019) O wybranych aspektach (nie)trafności "ewaluacji” reformowanego szkolnictwa wyższego. „Annales Universitatis Mariae Curie-Skłodowska, sectio N- Educatio Nova", t. 4 , s. 57-68.

Kamińska Kamila (2010) Dobro dziecka w dyskursie państwo-rodzina, inaczej o przemocy domowej. Kraków: Oficyna Wydawnicza „Impuls”.

Kochanowska Ewa (2017), Rozwijanie samodzielności poznawczej dziecka jako działanie (nie)pozorne nauczycieli w edukacji wczesnoszkolnej, "Zeszyty Naukowe Wyższej Szkoły Humanitas. Pedagogika", nr 14, s. 179-191.

Komenda Główna Policji [dostęp 20 kwietnia 2020 r.]. Dostępny w Internecie: 〈http://statystyka.policja.pl/st/wybrane-statystyki/zamachy-samobojcze».

Koweszko Tytus (2019) Dlaczego ktoś sam chce pozbawić się życia? [w:] Tytus Koweszko, red., Zatrzymać samobójstwo. Poradnik dla rodzin i bliskich. Warszawa: Medyk Sp. z o.o., s. 15-17.

Kubiak Anna, Krzewińska Aneta (2009) Działania pozorne $w$ procesie stanowienia prawa na przykładzie ustawy o lobbingu. „Przegląd Socjologiczny”, t. 58, nr 1, s. 33-49.

Kulesza Marta (2015) Zasoby rodzinne - nowa perspektywa podejścia do rodziny w obszarze diagnostyki i poradnictwa psychopedagogicznego [w:] Andrzej Najda, Agnieszka Regulska, red., Studia nad Rodzina. Warszawa: Wydawnictwo Uniwersytetu Kardynała Stefana Wyszyńskiego, s. 77-95.

Kupś Izabela, Pełka-Wysiecka Justyna, Samochowiec Jerzy (2007) Przymus bezpośredni - realizacja założeń Ustawy o ochronie zdrowia psychicznego wobec pacjenta zachowujacego się agresywnie w wybranych placówkach stużby zdrowia w województwie zachodniopomorskim. „Psychiatria”, t. 4, nr 3, s. 87-96.

Lewicka-Pańczak Katarzyna (2014) Samobójstwa młodzieży i osób dorostych w narracji psychologów [w:] Krzysztof Rosa, Adam Cza- bański, red., Percepcja zachowań samobójczych. Między opiniami a doświadczeniami. Kraków: Uniwersytet Medyczny w Łodzi, Polskie Towarzystwo Suicydologiczne, s. 49-72.

Lutyński Jan (1990) Nauka i polskie problemy. Komentarz socjologa. Warszawa: Państwowy Instytut Wydawniczy.

Lutyński Jan (1996) Działania pozorne [w:] Ewa Marynowicz-Hetka, Jacek Piekarski, red., Wokót problemów działania społecznego. Wybór tekstów i przykładów projektów działania. Warszawa: Wydawnictwo Interart, s. 125-138.

Maciejewska Fatima, Bury Przemysław (2008) Dysfunkcjonalność rodziny: psychologiczny i socjologiczny aspekt definicji. „Przegląd Naukowo-Metodyczny. Edukacja dla Bezpieczeństwa", nr 2, s. 26-41.

Maciejewska-Mroczek Ewa (2018) Dzieci, rodzice i praktykowanie zdrowia. Ujęcie childhood studies. „Niderlandystyka Interdyscyplinarnie", t. 3, nr 2, s. 24-32.

Makara-Studzińska Marta (2017) Formy pomocy osobom po próbach samobójczych. „Sztuka Leczenia”, nr 1, s. 53-61.

Miller Alice (1999) Zniewolone dzieciństwo. Ukryte źródła tyranii. Przełożyła Barbara Przybyłowska. Poznań: Media Rodzina Sp. z o.o.

Mills China (2018) Psychotropowe dzieciństwa. "Zdrowie Psychiczne na świecie" i dzieci na lekach [w:] Anna Witeska-Młynarczyk, red., Antropologia psychiatrii dzieci i młodzieży. Wybór tekstów. Warszawa: Oficyna Naukowa, s. 43-64.

Ministerstwo Zdrowia (2019) Zmiana planu finansowego NFZ na 2019 r. zatwierdzona 5 czerwca 2019 [dostęp 15 maja 2020 r.]. Dostępny w Internecie: 〈https://www.gov.pl/web/zdrowie/plany-finansowe-nfz'.

Naczelna Izba Lekarska (2020) Zestawienie liczbowe lekarzy i lekarzy dentystów wg dziedziny i stopnia specjalizacji [dostęp 24 maja 2020 r.]. Dostępny w Internecie: 〈https://nil.org.pl/uploaded_files/1588587497_zestawienie-nr-04.pdf .

Najwyższa Izba Kontroli (2020) Dostępność lecznictwa psychiatrycznego dla dzieci i młodzieży (w latach 2017-2019) [dostęp 30 września 2020 r.]. Dostępny w Internecie: 〈https://www.nik.gov. pl/plik/id,22730,vp,25429.pdf>.

Namysłowska Irena, Siewierska Anna (2009) Znaczenie i rola rodzeństwa w terapii rodzin. „Psychoterapia”, t. 149, nr 2, s. $45-56$. 
Nowakowska Karolina (2020) To nie jest kraj dla słabych ludzi. Drastyczny wzrost prób samobójczych wśród seniorów i dzieci [dostęp 30 września 2020 r.]. Dostępny w Internecie: 〈https://praca.gazetaprawna.pl/artykuly/1457138,samobojstwa-dzieci-i-seniorzy.html.

Ogólnopolskie Pogotowie dla Ofiar Przemocy w Rodzinie „Niebieska Linia” (2020) Raport podsumowujacy działalność [dostęp: 21 maja 2020 r.]. Dostępny w Internecie: 〈http://www.niebieskalinia.info/images/rok2019.pdf`.

Palińska Ewa (2019) Kryzys psychiatrii dziecięcej na Srebrzysku. Lekarze złożyli wypowiedzenia [dostęp 20 maja 2020 r.]. Dostępny w Internecie: 〈https://zdrowie.trojmiasto.pl/Koniec-psychiatrii-dzieciecej-na-Srebrzysku-Lekarze-zlozyliwypowiedzenia-n139692.html.

Palus Katarzyna (2006) Etiopatogeneza i terapia zaburzeń odżywiania się w perspektywie rodzinnej. "Roczniki socjologii rodziny", t. 17 , s. $235-253$.

Parys Katarzyna (2014) Zjawisko pozoru w systemie ksztatcenia uczniów niepetnosprawnych - próba identyfikacji i propozycje rozwiąań. „Interdyscy plinarne Konteksty Pedagogiki Specjalnej”, nr 4, s. 29-55.

Pinkosz Katarzyna (2020) Samobójstwa nastolatków: młodzi ludzie nie daja sobie rady ze światem [dostęp 30 września 2020 r.]. Dostępny w Internecie: 〈https://dorzeczy.pl/kraj/131203/samobojstwanastolatkow-mlodzi-ludzie-nie-daja-sobie-rady-ze-swiatem.html.

Poniatowska-Leszczyńska Katarzyna, Zinczuk-Zielazna Joanna (2014) Mechanizm wyparcia - teoria i badania. „Postępy Psychiatrii i Neurologii", nr 23, s. 117-123.

Radoń Ewa, Samochowiec Agnieszka (2017) Percepcja relacji rodzinnych a depresyjność młodzieży z rodzin o różnym typie. „Pomeranian Journal of Life Sciences", t. 63, nr 4, s. 82-87.

Rek-Woźniak Magdalena, Woźniak Wojciech (2013) Children Pushed Aside: Moral Panic over Families and the State in Contemporary Poland [w:] Charles Krinsky, ed., The Ashgate Research Companion to Moral Panics. Farnham, Burlington: Ashgate, s. 249-264.

Rek-Woźniak Magdalena, Woźniak Wojciech (2014) Dziecko, rodzina i państwo w polskiej debacie welfare. Analiza przypadku w perspektywie paniki moralnej. „Folia Sociologica”, nr 50, s. 43-67.

Rosa Krzysztof (2012) (Nie)wiarygodność danych statystycznych dotyczacych zachowań samobójczych. Perspektywa teoretyczna i praktyka społeczna. "Przegląd Socjologiczny”, t. 61, nr 2, s. 265-290.
Rosa Krzysztof, Czabański Adam, red. (2014) Percepcja zachowań samobójczych. Między opiniami a doświadczeniami. Kraków: Przygotowalnia Pracownia DTP i Grafiki.

Schwertner Janusz (2020) Miłość w czasach zarazy [dostęp 30 września 2020 r.]. Dostępny w Internecie: 〈https://wiadomosci.onet.pl/tylko-w-onecie/milosc-w-czasach-zarazy/ nbqxxwm>.

Siwek Stanisław (2010) Czynniki społeczne w genezie nieprawidłowego rozwoju i zachowania. „Acta Universitatis Lodziensis. Folia Psychologia", t. 14, s. 19-43.

Stanisławska-Kubiak Maia, Matecka Monika, Mojs Ewa (2010) Nastoletni pacjent po próbie samobójczej w szpitalu. „Pielęgniarstwo Polskie", nr 2, s. 104-108.

Stasiuk-Krajewska Karina (2014) Szpital jako instytucja totalna - dyskursywne i instytucjonalne uwarunkowania komunikacji. „Dziennikarstwo i Media”, vol. 5, s. 161-179.

Suchodolska Mira (2018) Oddział dziecięcy w Józefowie zamknięty. W całej psychiatrii w Polsce katastrofa [dostęp 20 maja 2020 r.]. Dostępny w Internecie: https://zdrowie.dziennik.pl/aktualnosci/artykuly/587171,oddzial-dzieciecy-psychatria-jozefowzamknieta.html>.

Sumiła Anita, Sulska Ewa (2006) Zachowania samobójcze u pacjentów hospitalizowanych psychiatrycznie na oddziale młodzieżowym. „Psychiatria”, t. 3, nr 3, s. 128-132.

Szarota Piotr (2018) Od Facebooka do post-przyjaźni. Wspótczesne przeobrażenia bliskich relacji. Warszawa: Wydawnictwo Naukowe PWN SA i Instytut Psychologii Polskiej Akademii Nauk.

Tillmann Klaus-Jürgen (2006) Teorie socjalizacji. Społeczność, instytucja, upodmiotowienie. Przełożyli Grzegorz Bluszcz, Bartek Miracki. Warszawa: Wydawnictwo Naukowe PWN.

Trawkowska Dobroniega (2007) Działania pozorne w pomocy społecznej - przypadek (i przypadłość) pracy socjalnej. „Problemy Polityki Społecznej. Studia i Dyskusje”, nr 10, s. 131-150.

Trawkowska Dobroniega (2009) Działania pozorne w pomocy społecznej - przejawy - mechanizmy - skutki. „Przegląd Socjologiczny", t. 58, nr 1, s. 129-147.

Tuszyńska-Bogucka Wioletta (2017) Etiologia samobójstwa w opinii publiczne. Metaanaliza weryfikacyjna [w:] Marek Mozgawa, red., Samobójstwo. Warszawa: Wolters Kluwer Polska SA, s. $403-422$. 
Witeska-Młynarczyk Anna (2018) Wyjątkowe dzieciństwo, wyjątkowa młlodość. Antropologia psychiatrii dzieci i młodzieży [w:] Anna Witeska-Młynarczyk, red., Antropologia psychiatrii dzieci i młodzieży. Wybór tekstów. Warszawa: Oficyna Naukowa, s. 7-42.

Witkowska Bogumiła (2013) Percepcja postaw rodzicielskich a poziom samooceny dziewczat $z$ anoreksja psychiczna. „Psychiatria Polska", t. 47, nr 3, s. 397-409.

Wróblewski Michał (2012) Polityka standardów. Konstruowanie pola obiektywności w diagnostyce psychiatrycznej na przykładzie DSM-III. „Kultura i Edukacja”, nr 4, s. 64-87.

Wróblewski Michał (2016) Choroby walizkowe. O globalizacji zaburzeń psychicznych [w:] Krzysztof Abriszewski, Adam F. Kola,
Jacek Kowalewski, red., Humanistyka (pót)peryferii. Olsztyn: Instytut Historii i Stosunków Międzynarodowych Uniwersytetu Warmińsko-Mazurskiego w Olsztynie, s. 23-54.

Zalewska-Łunkiewicz Karolina (2016) Samoocena młodych dorosłych w kryzysie pierwszorazowej hospitalizacji psychiatrycznej. "Czasopismo Psychologiczne. Psychological Journal", t. 22, nr 2, s. 269-275.

Ziółkowska Justyna (2016) Samobójstwo. Analiza narracji osób po próbach samobójczych. Warszawa: Wydawnictwo Naukowe PWN SA.

Zwoliński Andrzej (2013) Samobójstwo jako problem osobisty i publiczny. Kraków: Wydawnictwo WAM.

\section{Cytowanie}

Adamczyk Paulina (2021) Diagnoza: niemiłość? Działania pozorne a system wsparcia dzieci i młodzieży po próbach samobójczych. „Przegląd Socjologii Jakościowej", t. 17, nr 1, s. 114-134 [dostęp dzień, miesiąc, rok]. Dostępny w Internecie: «www.przegladsocjologiijakosciowej.org>. DOI: http://dx.doi.org/10.18778/1733-8069.17.1.08

\section{Diagnosis: Lovelessness. Apparent Actions and the System of Support for Children and Youth After Suicide Attempts}

Abstract: Despite the growing number of media reports about the severe crisis of the system of psychological and psychiatric care as well as related increase in the number of suicides and suicide attempts among children and youth, this subject is still absent from the political debate in Poland. Drawing on the review of relevant literature, statistical data, and media reports about children and youth psychiatry, this article attempts to describe selected contexts of this crisis in sociological terms. Special attention is paid to family relations - which are frequently a taboo topic in the Polish context - and their ambiguous influence on children and youth, also during the therapeutic process after the suicide attempts. The article also undertakes the theme of the institutional crisis of the Polish healthcare system regarding psychological and psychiatric care.

Keywords: suicide, suicide attempt, psychiatric care, apparent actions, the sociology of children and youth, family 